\title{
Simultaneous coastal measurements of ozone deposition fluxes and iodine-mediated particle emission fluxes with subsequent CCN formation
}

\author{
J. D. Whitehead, G. McFiggans, M. W. Gallagher, and M. J. Flynn \\ Centre for Atmospheric Science, The University of Manchester, Simon Building, Oxford Road, Manchester, M13 9PL, UK \\ Received: 14 September 2009 - Published in Atmos. Chem. Phys. Discuss.: 30 September 2009 \\ Revised: 14 December 2009 - Accepted: 22 December 2009 - Published: 13 January 2010
}

\begin{abstract}
Here we present the first observations of simultaneous ozone deposition fluxes and ultrafine particle emission fluxes over an extensive infra-littoral zone. Fluxes were measured by the eddy covariance technique at the Station Biologique de Roscoff, on the coast of Brittany, north-west France. This site overlooks a very wide $(3 \mathrm{~km})$ littoral zone controlled by very deep tides $(9.6 \mathrm{~m})$ exposing extensive macroalgae beds available for significant iodine mediated photochemical production of ultrafine particles. The aspect at the Station Biologique de Roscoff provides an extensive and relatively flat, uniform fetch within which micrometeorological techniques may be utilized to study links between ozone deposition to macroalgae (and sea water) and ultrafine particle production.

Ozone deposition to seawater at high tide was significantly slower $\left(v_{d}\left[\mathrm{O}_{3}\right]=0.302 \pm 0.095 \mathrm{~mm} \mathrm{~s}^{-1}\right)$ than low tidal deposition. A statistically significant difference in the deposition velocities to macroalgae at low tide was observed between night time $\left(v_{d}\left[\mathrm{O}_{3}\right]=1.00 \pm 0.10 \mathrm{~mm} \mathrm{~s}^{-1}\right)$ and daytime $\left(v_{d}\left[\mathrm{O}_{3}\right]=2.05 \pm 0.16 \mathrm{~mm} \mathrm{~s}^{-1}\right)$ when ultrafine particle formation results in apparent particle emission. Very high emission fluxes of ultrafine particles were observed during daytime periods at low tides ranging from 50000 particles $\mathrm{cm}^{-2} \mathrm{~s}^{-1}$ to greater than 200000 particles $\mathrm{cm}^{-2} \mathrm{~s}^{-1}$ during some of the lowest tides. These emission fluxes exhibited a significant relationship with particle number concentrations comparable with previous observations at another location. Apparent particle growth rates were estimated to be in the range $17-150 \mathrm{~nm} \mathrm{~h}^{-1}$ for particles in the size range $3-10 \mathrm{~nm}$. Under certain conditions, particle growth may be inferred to
\end{abstract}

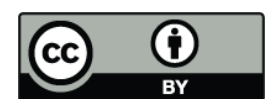

Correspondence to: G. McFiggans (g.mcfiggans@manchester.ac.uk) continue to greater than $120 \mathrm{~nm}$ over tens of hours; sizes at which they may readily behave as cloud condensation nuclei $(\mathrm{CCN})$ under reasonable supersaturations that may be expected to pertain at the top of the marine boundary layer. These results link direct depositional loss and photochemical destruction of ozone to the formation of particles and hence $\mathrm{CCN}$ from macroalgal emissions at a coastal location.

\section{Introduction}

Coastal new particle formation has been observed at a number of locations (see O'Dowd and Hoffmann, 2005, for a review). These nucleation events generally occur during the day and at low tide and have been known to result in ultrafine particle number concentrations in excess of $10^{6}$ particles $\mathrm{cm}^{-3}$ (O'Dowd et al., 2002b). If a significant fraction of such particles grow sufficiently, they will enhance cloud condensation nucleus (CCN) concentrations and hence affect the properties of coastal clouds (Pirjola et al., 2002; Saiz-Lopez et al., 2006). In recent years, these coastal particle bursts have been linked to iodine emissions from macroalgae exposed during low tide (McFiggans et al., 2004; McFiggans, 2005; Saiz-Lopez et al., 2006).

Seaweeds, and particularly brown kelps, have long been known to accumulate large amounts of iodine (in the form of iodide) in their tissue, sometimes at concentrations more than 30000 times greater that that of the surrounding seawater (Küpper et al., 1998, 2008). It was shown by Küpper et al. (2008) that this accumulated iodide acts as an inorganic antioxidant, and is released in large quantities when the seaweed is subjected to oxidative stress. When the seaweed is exposed to the atmosphere (for example at low tide),

Published by Copernicus Publications on behalf of the European Geosciences Union. 

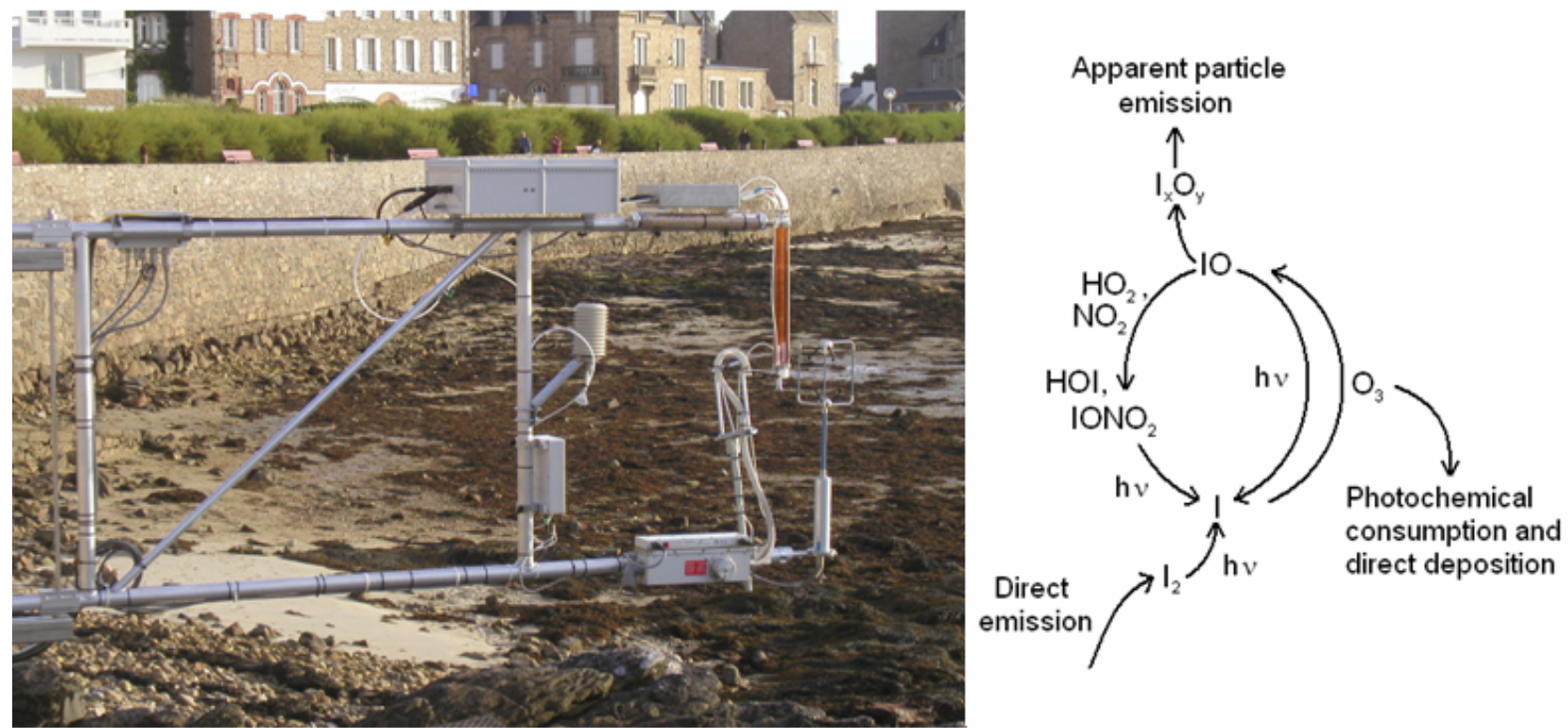

Fig. 1. The boom from which flux measurements were made during the RHaMBLe experiment. The panel on the right shows the photochemical processes that lead to particle production.

the iodide reacts rapidly with ozone in the film of water at the seaweed surface to form molecular iodine (Palmer et al., 2005; Küpper et al., 2008). A second ozone loss mechanism occurs during particle production. During daytime low tide, the photolysis of molecular iodine leads to enhanced concentrations of the iodine monoxide radical (IO), consuming ozone (Saiz-Lopez et al., 2004). The self-reaction of IO produces higher iodine oxides $\left(\mathrm{I}_{\mathrm{x}} \mathrm{O}_{\mathrm{y}}\right)$, which can in turn nucleate and grow to detectable sizes $(3 \mathrm{~nm})$ of iodine-containing aerosols (McFiggans et al., 2004; Saiz-Lopez et al., 2006). This results in a net consumption of ozone. The chemical pathways leading to particle formation are illustrated in the right panel of Fig. 1.

Laboratory incubation experiments on Laminaria $s p$. macroalgae (those comprising the highest percentage iodine dry weight and likely contributing to the greatest iodine emission on intertidal exposure; see Ball et al., 2009; Leigh et al., 2009) showed that the amount of ozone consumed in macroalgal exposure experiments depends on the initial ozone concentration (Küpper et al., 2008) with a first order loss rate of $0.0115 \mathrm{~s}^{-1}$. From this, an apparent ozone deposition velocity to the macroalgal sample of between 2.5 and $10 \mathrm{~mm} \mathrm{~s}^{-1}$ was derived (assuming a typical range for aerodynamic resistance). This is at least an order of magnitude greater than the value of $0.3 \mathrm{~mm} \mathrm{~s}^{-1}$ determined for deposition to seawater (Chang et al., 2004), and is also greater than the upper limit of $1.0 \mathrm{~mm} \mathrm{~s}^{-1}$ estimated by Clifford et al. (2008) based on the reaction of ozone with chlorophyll in the surface marine layer. Enhanced ozone deposition velocities may therefore be expected to be seen over exposed infra-littoral macroalgal beds. It may be expected that, because of the highly enriched iodide concentrations in the macroalgal apoplast (Küpper et al., 2008), molecular iodine formation through reaction of ozone with iodide at the surface of exposed macroalgae will lead to an increased ozone deposition. During the day, the apparent enhancement in deposition velocity will be enhanced further through photochemical destruction on top of the direct depositional loss. This study presents such direct measurement of apparent ozone deposition and particle production at a coastal location.

The deposition rate of ozone to sea surfaces is an important quantity, likely controlled by many complex physical and chemical processes (Schwartz, 1992). Quantifying its magnitude and behaviour is important in many model studies that attempt to link detailed chemical processes in the background marine boundary layer with ozone destruction. Direct measurements of ozone exchange to water and sea surfaces are sparse, and there is large variability in reported net deposition velocities $\left(v_{d}\right)$. Measurements by Gallagher et al. (2001) suggested a significant wind speed dependence on ozone exchange was evident in previously reported data in line with ideas of enhanced uptake due to turbulence enhanced molecular diffusion (Liss and Merlivat, 1986). Recently modelling work by Chang et al. (2004), suggested $v_{d}$ can vary by more than a factor of 5 as wind speeds increase from 0 to $20 \mathrm{~m} \mathrm{~s}^{-1}$. This variation can have significant consequences for chemical box model studies of, for example, halogen mediated ozone destruction in marine surface layers (Gallagher et al., 2001). Modelling studies attempting to link enhanced surface reactivity based on a number of species known to react with ozone in water are still speculative but iodide has been 
hypothesised as the most likely candidate due to its reported relatively wide range of ocean surface concentrations (20$400 \mathrm{nM}$; Chang et al., 2004). Martino et al. (2009) reported the formation of volatile organic iodine compounds produced from the reaction of marine dissolved organic matter with hypoiodous acid/molecular iodine, which are formed at the sea surface when ozone reacts with dissolved iodide. Such a mechanism would result in an abiotic enhancement of ozone deposition in open waters. Although we cannot address the surface reactivity issue quantitatively here we provide a significant addition to available observations that we believe provides a more reliable lower limit than hitherto available previously for $v_{d}\left[\mathrm{O}_{3}\right]$ to sea water.

This paper extends the findings of Whitehead et al. (2009) and discusses them in more detail with respect to previous work.

\section{Methods}

\subsection{Site and measurements}

The measurements were conducted at the Station Biologique de Roscoff $\left(48^{\circ} 44^{\prime} \mathrm{N}, 3^{\circ} 59^{\prime} \mathrm{W}\right)$, in a coastal town in Brittany in the north-west of France, during September 2006, as part of the coastal experiment of the Reactive Halogens in the Marine Boundary Layer (RHaMBLe) project. The maximum tidal range at this site is $9.6 \mathrm{~m}$, and at the lowest tides this results in an infra-littoral zone of up to $3 \mathrm{~km}$ from the measurement site, consisting of extensive macroalgae beds. Instruments were situated on the shoreline at the start of a low stone jetty outside the Station Biologique de Roscoff. This location provided a fetch of at least $800 \mathrm{~m}$, and up to several kilometres over the inter-tidal zone for a wind direction of between $215^{\circ}$ and $005^{\circ}$. Further details of the site are outlined in McFiggans (2009).

Direct fluxes of ultrafine particles and ozone were measured using the eddy covariance technique (see below). The instrumentation included a sonic anemometer (Gill UK Model R3-50) with a resolution of $\pm 0.01 \mathrm{~m} \mathrm{~s}^{-1}$ and a frequency response of $50 \mathrm{~Hz}$. Water vapour fluctuations were also measured using a Krypton UV absorption hygrometer (Model KH2O, Campbell Scientific Ltd.), co-located with the sonic anemometer in order to determine latent heat fluxes (the $\mathrm{KH} 2 \mathrm{O}$ has a reported frequency response of $>50 \mathrm{~Hz}$ ). Absolute temperature and humidity were measured using a Vaisala sensor (Model PTR-100/Humicap). All the instruments were mounted on a specially constructed boom protruding $5 \mathrm{~m}$ past the edge the jetty. The boom was capable of being traversed vertically to accommodate the very large changes in tidal height and could be swung horizontally to accommodate different wind fetches. However this was not considered necessary in the conditions experienced during the experiment and for the flux measurements, the instruments were fixed at a height of $3.4 \mathrm{~m}$ above the seafloor (The tide height, when the water is level with the seafloor at the measurement location, is $5.6 \mathrm{~m}$ ). Figure 1 shows the mast arrangement deployed in the RHaMBLe experiment.

In order to ensure that the presence of the jetty wall was not influencing the air flow at the sensor location, the vertical wind angle was examined. This was not found to deviate by more than a few degrees from the horizontal and was within the range observed and presented in previous publications (e.g. Gallagher et al., 2001). In addition, the values of the variances of the vertical and horizontal wind velocities, normalised by the local stress (momentum flux) are consistent with measurements over a flat uniform terrain, indicating the flows were not significantly perturbed by any bluff body (Foken and Wichura, 1996).

\subsection{The eddy covariance technique}

The eddy covariance (EC) technique is the simplest, most direct method for measuring vertical exchange fluxes of atmospheric constituents. It is based on the Reynolds decomposition of a turbulent quantity such as concentration $(\chi)$ into its time-averaged component $(\bar{\chi})$, and its instantaneous perturbation $\left(\chi^{\prime}\right)$ :

$\chi=\bar{\chi}+\chi^{\prime}$

The vertical flux of $\chi$ is then defined as the covariance between $\chi$ and the vertical component of wind speed, $w$ (e.g. Foken and Wichura, 1996):

$F_{\chi}=\overline{w^{\prime} \chi^{\prime}}=\overline{w \chi}-\overline{w \chi}$

Online fluxes of particles and ozone were calculated using EC within the same software, for 15 min averaging periods. Spectral analysis (the ogive method described by Foken, 2006) showed that 15 min were sufficient to measure most of the low frequency eddies contributing to the flux at this location and measurement height, while being short enough to minimise instationarities resulting from violation of the steady-state assumption of the EC technique. Aerosol and trace gas time series data were treated automatically for lag times induced by sampling down the inlets, and 3-D geometric coordinate rotations were performed on the fluxes to correct for any deviations in the alignment of the sonic anemometer. These correction were relatively small and were of the order of $1 \%$. The ozone flux data were also corrected to account for density fluctuations using the method of Webb et al. (1980). This resulted in increasing the flux values by approximately $14 \%$. Fluxes were rejected if conditions were considered to be non-stationary (using the criterion described by Foken and Wichura, 1996), or if the average wind direction was from outside the sea fetch defined by the range $215^{\circ}$ to $005^{\circ}$. This choice of wind sector takes into account the shape of the coastline, and there is not expected to be significant influence from the land. Of the data collected during sea fetch conditions, around $66 \%$ were rejected due to nonstationarities and other quality controls. 


\subsection{The resistance analogy}

Turbulent transport of atmospheric trace gases and particles to a surface may be discussed in terms of the resistance analogy (e.g. Gallagher et al., 2001). The total resistance $\left(r_{t}\right)$ to deposition of a scalar to a surface is given by:

$r_{t}=-\frac{\chi(z-d)}{F_{\chi}}=v_{d}^{-1}(z-d)$

where $v_{d}$ is the deposition velocity to the surface from a given height $z-d$ where $z$ is the measurement height, and $d$ the zero-plane displacement height. The total resistance may be considered as the sum of the aerodynamic resistance $\left(r_{a}\right)$, the laminar sub-layer resistance $\left(r_{b}\right)$, and the surface resistance $\left(r_{s}\right)$. The aerodynamic resistance describes the resistance experienced in turbulent transport from the measurement height $(z)$ down to the roughness length $\left(z_{0}\right)$ above the surface. An expression for $r_{a}$, derived by Garland (1977), is given by:

$r_{a}(z-d)=\frac{u(z-d)}{u_{*}^{2}}-\frac{\psi_{H}(z / L)-\psi_{M}(z / L)}{\kappa u_{*}}$

where $u$ is the wind speed, $u_{*}$ is the friction velocity, $L$ is the Obukhov length (a measure of stability), $\kappa$ is the von Kármán constant (0.41), and $\psi_{H}$ and $\psi_{M}$ are the integrated stability functions for heat and momentum, respectively, which may be approximated by the analytical solutions derived by Paulson (1970). The second term in Eq. (4) vanishes for stable and neutral conditions.

The laminar sub-layer resistance describes the molecular diffusion across the laminar boundary layer in direct contact with the surface and there are various different parameterisations of $r_{b}$ in the literature (e.g. Owen and Thomson, 1963; Chamberlain, 1966; Gallagher et al., 2001). However, these parameterisations disagree significantly with each other when applied to the data presented here. Kondo (1975) discusses this process over seawater and shows a strong dependence on the surface roughness due to wind speed. In any case, $r_{b}$ is small compared to $r_{s}$ (based on calculations using a number of these parameterisations) and so will be neglected here. Finally $r_{s}$ is the resistance to uptake at the surface and may be found by subtracting $r_{b}$ and $r_{a}$ from $r_{t}$.

\subsection{Ozone fluxes}

Eddy covariance flux measurements of ozone were made with using a fast response ozone sensor (GFAS model OSG-2; see Güsten et al., 1992; Güsten and Heinrich, 1996), which is based on the chemiluminescent reaction of ozone on the surface of a $25 \mathrm{~mm}$ silica gel disk impregnated with a layer of coumarin- 47 reactive dye solution. The disks, presensitised by exposure to approximately $100 \mathrm{ppb}$ of ozone for $3 \mathrm{~h}$, were replaced typically every $48-72 \mathrm{~h}$ depending on the ambient accumulated ozone concentration and water vapour. The instrument has a quoted response time of $20 \mathrm{~Hz}$, and a detection limit of $50 \mathrm{pptv}$, making it suitable for eddy covariance flux measurements. The instrument does not measure absolute concentrations of ozone, and so required calibration against a slower response Thermo Electron Corporation ozone analyser (Model 49, limit of detection $1 \mathrm{ppbv}$, response time $20 \mathrm{~s}$ ). A calibration on every $15 \mathrm{~min}$ ozone flux measurement was sufficient for this purpose as the drift in calibration was slow and monotonic. Use of the GFAS for ozone flux measurements, including data quality control, analysis techniques and sources of uncertainty, are discussed extensively by Muller et al. (2009).

\subsection{Ultrafine particle fluxes}

In addition to ozone, fluxes of ultrafine particles were measured using an eddy covariance system comprising two ultrafine condensation particle counters (TSI models CPC 3010AS and UCPC 3776, which was replaced by a UCPC 3025AS on 11 September; e.g. Agarwal and Sem, 1980). These are capable of measuring total particle concentrations with sizes greater than a specific value determined by the instruments operating characteristics. The UCPC $3025 \mathrm{AS}$ has a 50\% detection efficiency for particles at $3 \mathrm{~nm}$ diameter. This efficiency rises to $90 \%$ detection for $5 \mathrm{~nm}$ diameter particles. The UCPC 3776 is able to detect particles down to $2.5 \mathrm{~nm}$ with a $50 \%$ efficiency, and an almost $100 \%$ efficiency for $3 \mathrm{~nm}$ particles. The CPC 3010 has a $50 \%$ efficiency for $10 \mathrm{~nm}$ particles. The non-step nature of the lower size limit of these instruments is likely to introduce errors when comparing results from two CPCs, which depends on the efficiency curve of the respective instruments. This may be particularly important when attempting to calculate a growth rate from the delay in response to a particle burst between two different CPCs (see Sect. 4.3). Background count levels for these instruments are typically 0.0001 particles $\mathrm{cm}^{-3}$ with an absolute accuracy of $\pm 10 \%$ although this can degrade with prolonged use. Details describing the use of these and similar particle counters to measure particle fluxes over different surfaces can be found in Buzorius et al. (1998) (forest surfaces), Dorsey et al. (2002) and Mårtensson et al. (2006) (urban surfaces), and Nemitz et al. (2002) (grasslands). A detailed review of micrometeorological methodologies and analysis techniques suitable for particle flux estimation can be found in Pryor et al. (2008).

The eddy flux systems used here provided measurements of $F_{D_{p}>3}$ (flux for particles with sizes $D_{p}>3 \mathrm{~nm}$ ) and $F_{D_{p}>10}$, (flux for particles with sizes $D_{p}>10 \mathrm{~nm}$ ). The difference between these, $\Delta F=F_{D_{p}>3}-F_{D_{p}>10}$, may be used as a useful indicator of a nucleation particle emission event, as well as providing a crude measure of the net nucleation particle flux (strictly speaking this will depend on the discrete nature of the distribution between these size limits). It should be noted that this method does not take into account changing particle sizes due to changing relative humidity. However, even if the particles were highly hygroscopic, 


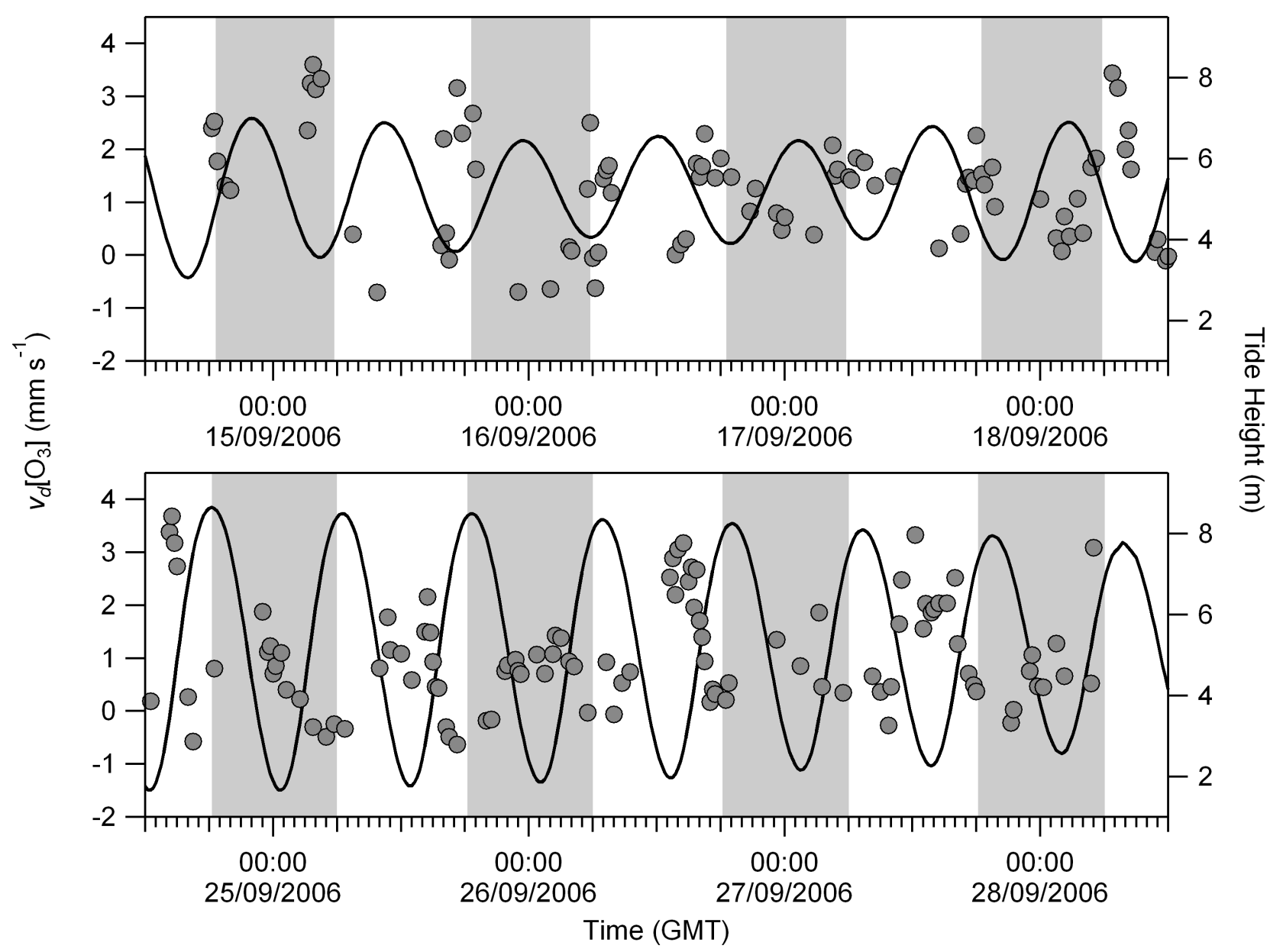

Fig. 2. Time-series of $v_{d}\left[\mathrm{O}_{3}\right]$ (filled grey circles) for two different periods during the experiment at Roscoff. The tidal height is shown by the black trace. The grey shaded areas represent night-time.

the fluctuations in particle size due to fluctuations in $\mathrm{RH}$ on timescales of $0.1 \mathrm{~s}$ would be very small, and the effect on particle flux measurements would therefore be negligible.

\subsection{Particle size distributions}

The aerosol size distribution was measured using a combination of a Scanning Mobility Particle Sizer (SMPS, TSI Model 3080L) and an optical particle counter (OPC, GRIMM Model 1.108). The SMPS was operated using a "long" Differential Mobility Analyser (DMA) column (TSI model $3080 \mathrm{~L}$ ) to size particles in the range $10-505 \mathrm{~nm}$ (mobility diameter). The GRIMM OPC sized particles in the range $0.3-20 \mu \mathrm{m}$ (optical scattering diameter) in 16 size channels but these data will not be reported here.

\section{Results}

\subsection{Ozone fluxes}

The mean ozone concentration during the experiment was $30 \mathrm{ppb}$, and ranged from $2 \mathrm{ppb}$ to $54 \mathrm{ppb}$. Following rejection of non-stationary flux data and other quality controls, 330 15-min flux periods remained. Measured ozone fluxes ranged from $-3.4 \mathrm{mg} \mathrm{m}^{-2} \mathrm{~s}^{-1}$ to $1.0 \mathrm{mg} \mathrm{m}^{-2} \mathrm{~s}^{-1}$ (where negative values denote downward flux) with a mean of $-0.060 \pm 0.014 \mathrm{mg} \mathrm{m}^{-2} \mathrm{~s}^{-1}$ (standard error). The mean ozone deposition velocity $\left(v_{d}\left[\mathrm{O}_{3}\right]\right)$ was $0.96 \mathrm{~mm} \mathrm{~s}^{-1}$ with a standard error of $\pm 0.15 \mathrm{~mm} \mathrm{~s}^{-1}$ (where deposition is denoted by a positive value). Figure 2 shows time-series plots of $v_{d}\left[\mathrm{O}_{3}\right]$ for two periods during the experiment when a prolonged sea fetch was seen. It can be seen that $v_{d}\left[\mathrm{O}_{3}\right]$ was, on average, greater during low tide than during high tide. Mean high tide $v_{d}\left[\mathrm{O}_{3}\right]$ was $0.302 \mathrm{~mm} \mathrm{~s}^{-1}$ (standard error $\pm 0.095 \mathrm{~mm} \mathrm{~s}^{-1} ; n=109$ ), while the mean low tide $v_{d}\left[\mathrm{O}_{3}\right]$ 


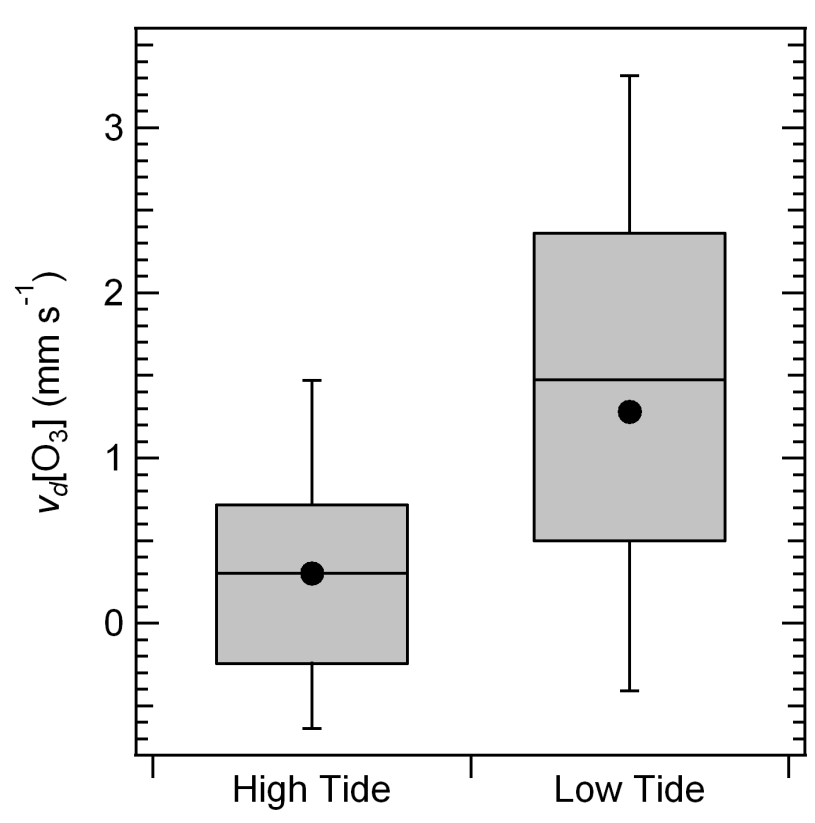

Fig. 3. Comparison of $v_{d}\left[\mathrm{O}_{3}\right]$ values between low and high tide for the whole experimental period. The medians and inter-quartile ranges are shown (boxes) along with the 10-90\% ranges (whiskers) and means (filled black circles).

was more than four times greater at $1.28 \mathrm{~mm} \mathrm{~s}^{-1}$ (standard error $\pm 0.22 \mathrm{~mm} \mathrm{~s}^{-1} ; n=221$ ). Low tide is defined here when the sea floor was exposed, that is when the tide height is below $5.6 \mathrm{~m}$. The difference between these values was found to be statistically significant $(p<0.005)$, and they can be compared in Fig. 3. In the period from 24 to 28 September, low tide occurred in the middle of the day and the middle of the night. During this period, the mean night-time low tide $v_{d}\left[\mathrm{O}_{3}\right]$ was $1.00 \pm 0.10 \mathrm{~mm} \mathrm{~s}^{-1}$ (standard error; $n=31$ ). Mean $v_{d}\left[\mathrm{O}_{3}\right]$ during daytime low tide was found to be statistically significantly higher $(p<0.001)$ at $2.05 \pm 0.16 \mathrm{~mm} \mathrm{~s}^{-1}$ (standard error; $n=39$ ). However the night-time deposition velocities were still significantly higher $(p<0.001)$ than those observed at high tide during the same period. These data are summarised in Fig. 4a. This is compared to values of $v_{d}\left[\mathrm{O}_{3}\right]$ measured between 14 and 18 September in Fig. 4b, when the tidal amplitude was smaller and low tide occurred mainly in the morning and evening. While there is still a significant $(p<0.001)$ difference between high and low tide, no statistically significant difference was found between daytime and night-time low tide, most likely due to low tide occurring in the transition between day and night. The mean $v_{d}\left[\mathrm{O}_{3}\right]$ at low tide was $1.61 \pm 0.13 \mathrm{~mm} \mathrm{~s}^{-1}$ (standard error; $n=64$ ).

\subsection{Particle measurements}

A number of particle bursts were observed at low tide during the daytime, lasting around $5 \mathrm{~h}$, and were particularly
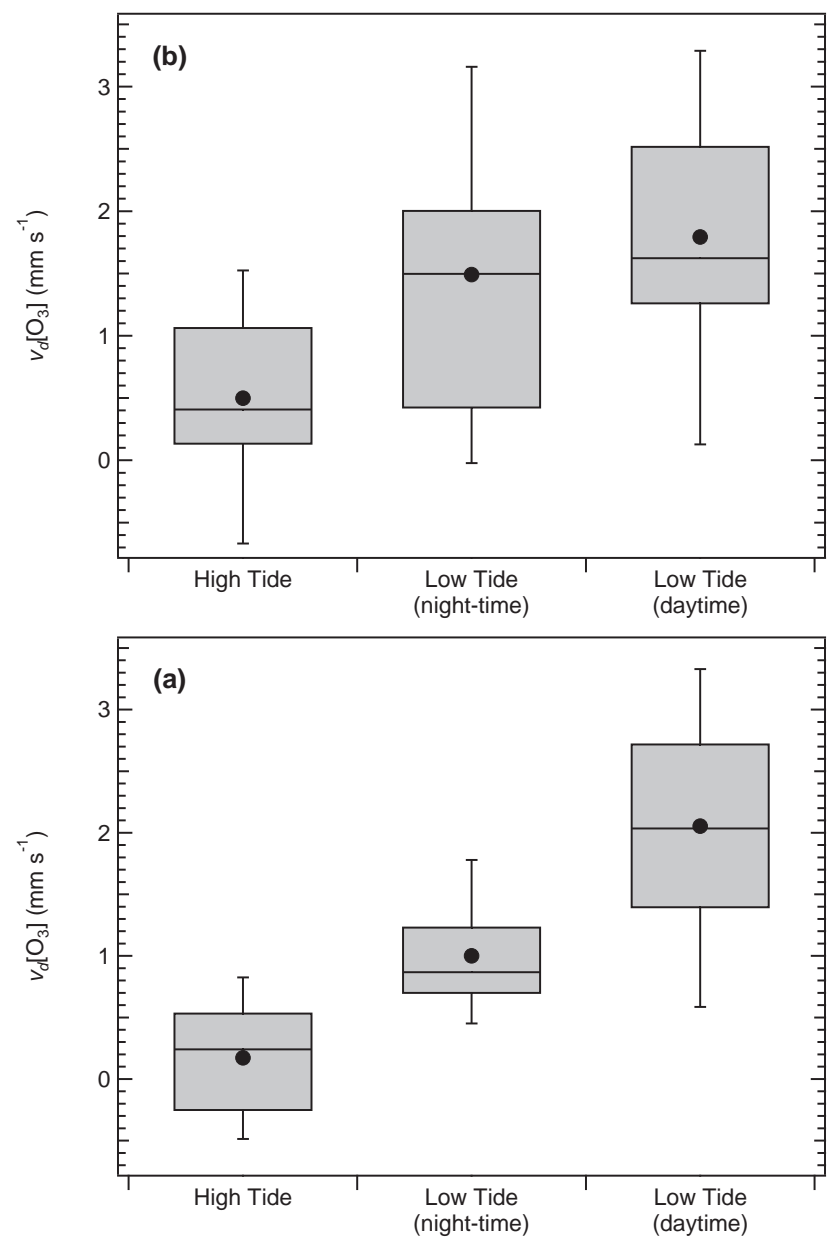

Fig. 4. (a) Comparison of $v_{d}\left[\mathrm{O}_{3}\right]$ values between different conditions during the period of 24-28 September 2006. The medians and inter-quartile ranges are shown (boxes) along with the 10-90\% ranges (whiskers) and means (filled black circles). (b) Comparison of $v_{d}\left[\mathrm{O}_{3}\right]$ values between different conditions during the period of 14-18 September 2006. The medians and inter-quartile ranges are shown (boxes) along with the 10-90\% ranges (whiskers) and means (filled black circles).

strong during the period of greatest tidal range from 7 to the 11 September. During these events, mean particle number concentrations were as high as 95000 particles $\mathrm{cm}^{-3}$, reaching peaks of around $2.5 \times 10^{5}$ particles $\mathrm{cm}^{-3}$. The time-series of particles greater than $10 \mathrm{~nm}$ shows much smaller increases in number concentration, confirming the bursts are comprised mostly of nucleation mode particles. In situ SMPS size distribution measurements (Fig. 5) show the apparent growth of these particles to sizes greater than $120 \mathrm{~nm}$, where they could be readily expected to behave as cloud condensation nuclei. This period of spring tides consisted mostly of winds from the north-east, which came from over the infralittoral zone, but beyond the fetch for reliable flux measurements. However, good fetch and stationary conditions were 

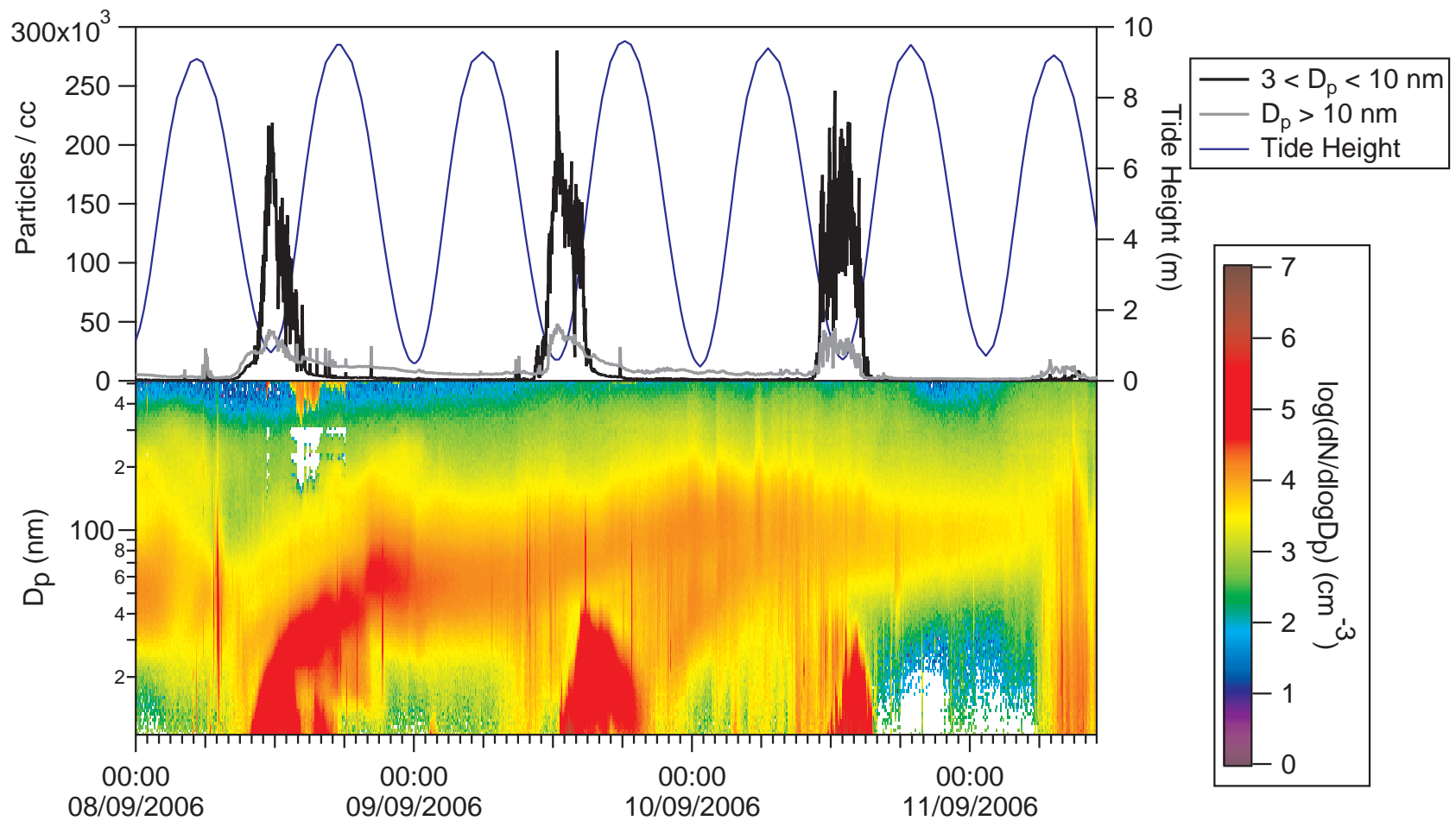

Time (GMT)

Fig. 5. Ultrafine particle concentrations (top panel) along with the number size distribution from the SMPS (bottom panel) during the period of 8-10 September 2006. Also shown is the tidal height.

observed on 25 and 26 September, during which particle bursts of up to $10^{5}$ particles $\mathrm{cm}^{-3}$ were observed. Figure 6 illustrates where the strongest particle bursts were coming from. Nucleation mode particle number concentrations (estimated by subtracting the number concentrations of particles greater than $10 \mathrm{~nm}$ from those greater than $3 \mathrm{~nm}$ ), are shown in Fig. 7 along with fluxes of particles greater than $3 \mathrm{~nm}$, and $v_{d}\left[\mathrm{O}_{3}\right]$ for this period. Apparent net particle emission fluxes of up to $2 \times 10^{5}$ particles $\mathrm{cm}^{-2} \mathrm{~s}^{-1}$ can be seen during daytime low tide corresponding with the particle bursts and the highest values of $v_{d}\left[\mathrm{O}_{3}\right]$ (up to $3 \mathrm{~mm} \mathrm{~s}^{-1}$ ). Strong particle emission fluxes were not observed during night-time low tides.

\section{Discussion}

\subsection{Ozone deposition at high tide}

The deposition velocity at high tide is assumed to represent direct deposition to the sea surface unaffected by chemical processes. A review of previous measurements shows quite a range in observed deposition velocities to sea surfaces (Gallagher et al., 2001; Chang et al., 2004; Fairall et al., 2007). This large variation in values has been attributed partly to an observed increase in $v_{d}\left[\mathrm{O}_{3}\right]$ with wind speed (Gallagher et

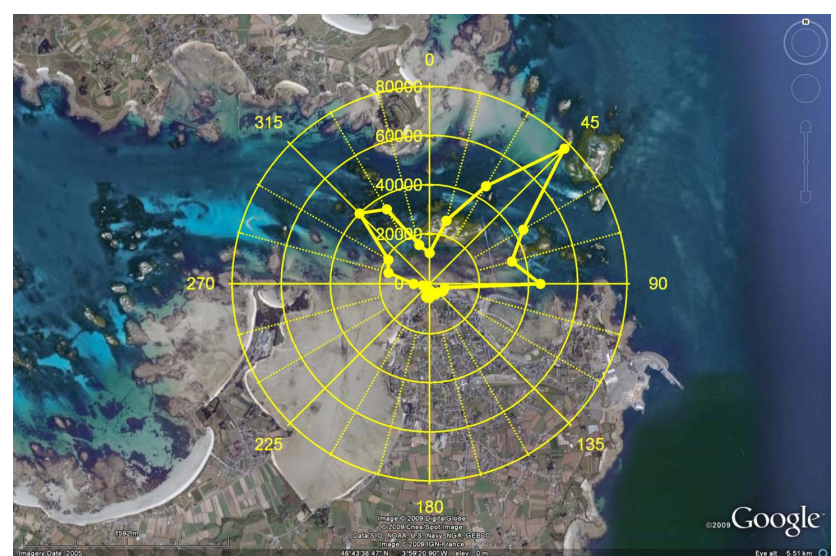

Fig. 6. Average ultrafine particle number concentrations plotted as a function of wind direction.

al., 2001; Chang et al., 2004), however this mainly occurs at high wind speeds (i.e. $u>4 \mathrm{~m} \mathrm{~s}^{-1}$ )(Chang et al., 2004). In this study, the mean wind speed was $3.2 \mathrm{~m} \mathrm{~s}^{-1}$ and ranged from $0-7.8 \mathrm{~m} \mathrm{~s}^{-1}$. However, for the majority of the time (about $75 \%$ ) it remained below $4 \mathrm{~m} \mathrm{~s}^{-1}$, so based on the work of Chang et al. (2004), no relationship between $v_{d}\left[\mathrm{O}_{3}\right]$ and wind speed was expected, nor was any seen. A large variation in deposition velocities reported by the various studies is 


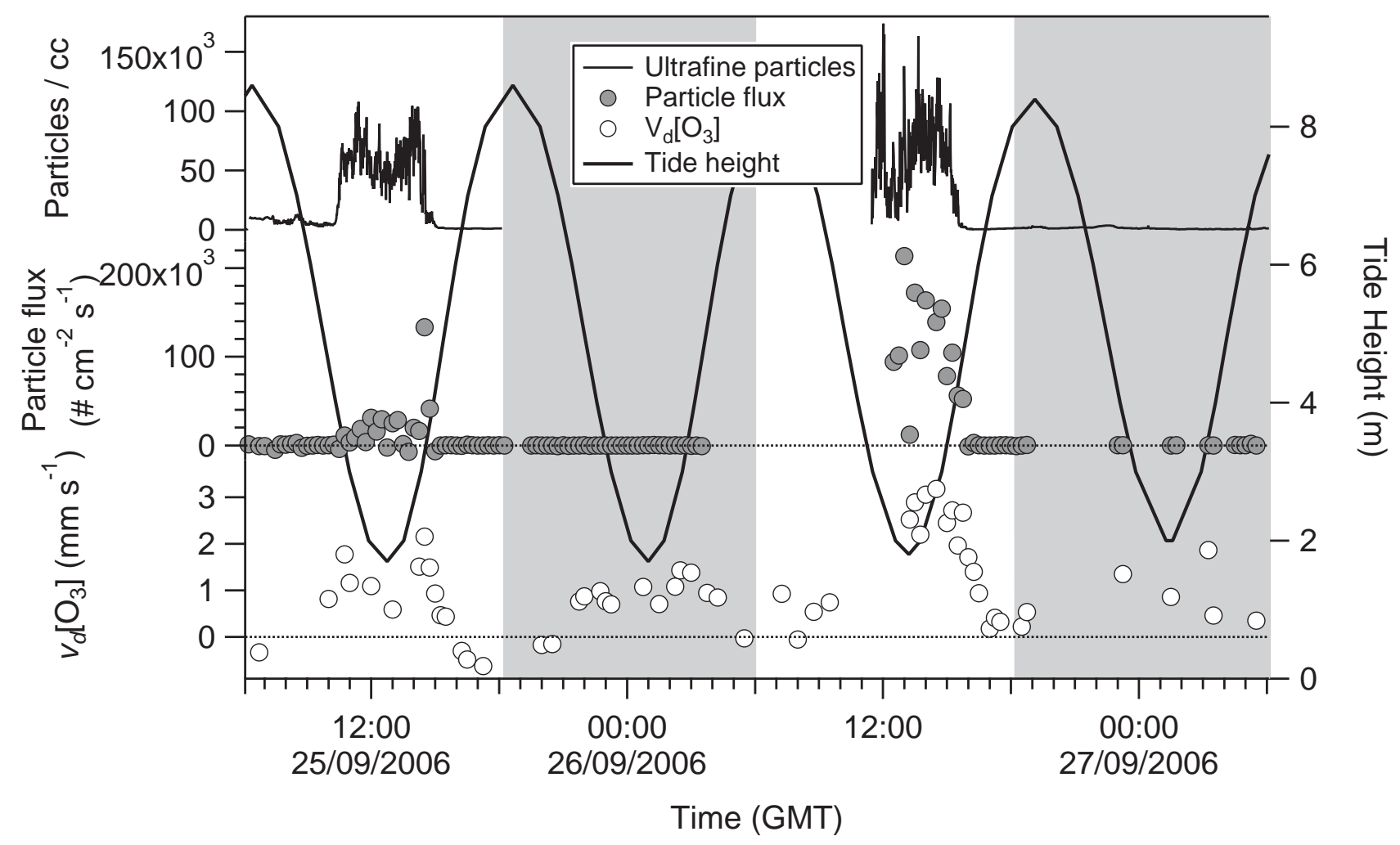

Fig. 7. Time-series of ultrafine particle number concentration (thin black trace at the top), particle flux for particles in the size range 3-10 nm (filled grey circles, middle) and $v_{d}\left[\mathrm{O}_{3}\right]$ (white circles, bottom). The thick black trace shows the tidal height. Night-times are represented by the grey shaded areas.

also observed at low wind speed, which may be due to large spatial and temporal variability in ocean chemistry (Chang et al., 2004).

The mean sea-surface resistance, based on measurements made at high tide at Roscoff, was calculated to be $r_{s}=1150 \pm 150 \mathrm{~s} \mathrm{~m}^{-1}$. The median value of $r_{s}$ was $1690 \mathrm{~s} \mathrm{~m}^{-1}$ ). These values are within the range suggested by Gallagher et al. (2001) of $950-1890 \mathrm{~s} \mathrm{~m}^{-1}$ based on a review of previous micrometeorological measurements of ozone deposition to seawater. Gallagher et al. (2001) note that sea surface roughness may be enhanced by breaking waves where there is an extensive shallow coastal shelf, resulting in a reduction in surface resistance. This may be one reason why the mean $r_{s}$ observed here is lower than the values calculated from measurements over open-ocean. Higher ozone deposition velocities were also observed in coastal waters than in the open ocean during a cruise near the coast of Texas in the Gulf of Mexico (Bariteau et al., 2009). Preliminary analysis by Bariteau et al. (2009) found a mean $v_{d}\left[\mathrm{O}_{3}\right]$ of $0.34 \pm 0.03 \mathrm{~mm} \mathrm{~s}^{-1}$ over open ocean, rising to $0.65 \pm 0.19 \mathrm{~mm} \mathrm{~s}^{-1}$ near the coast once influences from the land had been removed.

\subsection{Ozone deposition and particle formation}

The surface resistance to ozone deposition during night-time low tide was found to be $650 \pm 46 \mathrm{~s} \mathrm{~m}^{-1}$. This is lower than that observed at high tide $\left(1150 \pm 150 \mathrm{~s} \mathrm{~m}^{-1}\right.$, both daytime and night-time). This is due to enhanced uptake at the exposed seaweed surface due to the release of high levels of iodide by the macroalgae. Direct deposition to the seaweed surface forms the dominant loss mechanism of ozone at night time low tide. Küpper et al. (2008) predicted an order of magnitude difference between the surface resistance of seawater and that of exposed Laminaria digitata $\left(r_{s}=100\right.$ $400 \mathrm{~s} \mathrm{~m}^{-1}$ to the seaweed based on the ozone removal rate observed during chamber measurements). Their value for $r_{s}$ to seaweed assumes uniformly distributed Laminaria surface to which ozone deposits. It may therefore be considered a lower limit for surface resistance to an exposed seafloor with non-uniformly distributed Laminaria beds amongst other species of seaweed since deposition will be slower to nonseaweed surfaces.

During the daytime low tide periods, gas phase photochemical destruction provides an additional removal mechanism for ozone, which reacts with atmospheric iodine generated by the photolysis of iodine emitted by the exposed macroalgae. This is expected to result in higher values of 
$v_{d}\left[\mathrm{O}_{3}\right]$ during the day than at night (low tide). Indeed, at Roscoff, average low tide values of $v_{d}\left[\mathrm{O}_{3}\right]$ were twice as high during the day as they were at night (see Fig. 4). It is this photochemical reaction that leads to coastal particle formation, resulting in the observation of strong net apparent particle emission fluxes and hence concentrations during daytime low tide. This is consistent with observations of particle bursts at other coastal sites (O'Dowd et al., 1998, 2002b) and also in laboratory experiments using chambers (O'Dowd et al., 2002a; McFiggans et al., 2004; Palmer et al., 2005).

It should be noted that due to the fixed position of the instrumentation during flux measurements, the measurement height effectively changed with the tides. Exactly how this affects the flux measurements will be the focus of further work. However the patterns in ozone deposition velocities and particle emission fluxes are more consistent with the picture of macroalgal emissions than with the effects of sensor height. Apparent particle emission fluxes, for example, are only seen during daytime low tide and are not seen during night time low tide. In addition, low tide apparent ozone deposition velocities were stronger during the daytime compared to night time due to gas phase photochemical destruction while there was no significant difference at high tide between daytime and night time. In any case, the stronger ozone sink and particle source in the low tide footprint would still result in higher fluxes than at high tide.

\subsection{Particle size spectra and growth rates}

It can be seen from the particle size spectrum time-series in Fig. 5 that the increase in number concentration following the particle production events on 8 and 9 September is propagated continuously through to larger sizes which persist at the measurement site into the afternoon of the 10 September. The particles are formed at diameters of less than $2.5 \mathrm{~nm}$, observed only once they have reached $2.5 \mathrm{~nm}$ (by the difference in CPC measurements), and grow to sizes of greater than $120 \mathrm{~nm}$ on a timescale of tens of hours. Particle growth rates may be estimated from the rate of change of the mode in the size distribution (e.g. Dal Maso et al., 2002). Using this method for the particle bursts seen on 8 and 9 September, an apparent growth rate of $10-15 \mathrm{~nm} \mathrm{~h}^{-1}$ is seen. This growth rate decreases with time as the plume is diluted, and since the lower size cut-off of the SMPS during these measurements was $10 \mathrm{~nm}$, it may be reasonably assumed that growth rates are higher at smaller sizes. This can be estimated by comparing the times at which the number concentrations recorded by the two CPCs increase due to a nucleation event. The time delay between the two instruments may be regarded as the time taken for particles to grow from $2.5 \mathrm{~nm}$ (or $3 \mathrm{~nm}$ when the UCPC $3025 \mathrm{AS}$ was operating) to $10 \mathrm{~nm}$. It must be noted that this assumes a step change in the response of the CPCs at their lower size cut-off (see Methods, Sect. 2 for a discussion on this). Using this method for nucleation events throughout the experiment, the particle growth rate was estimated in the

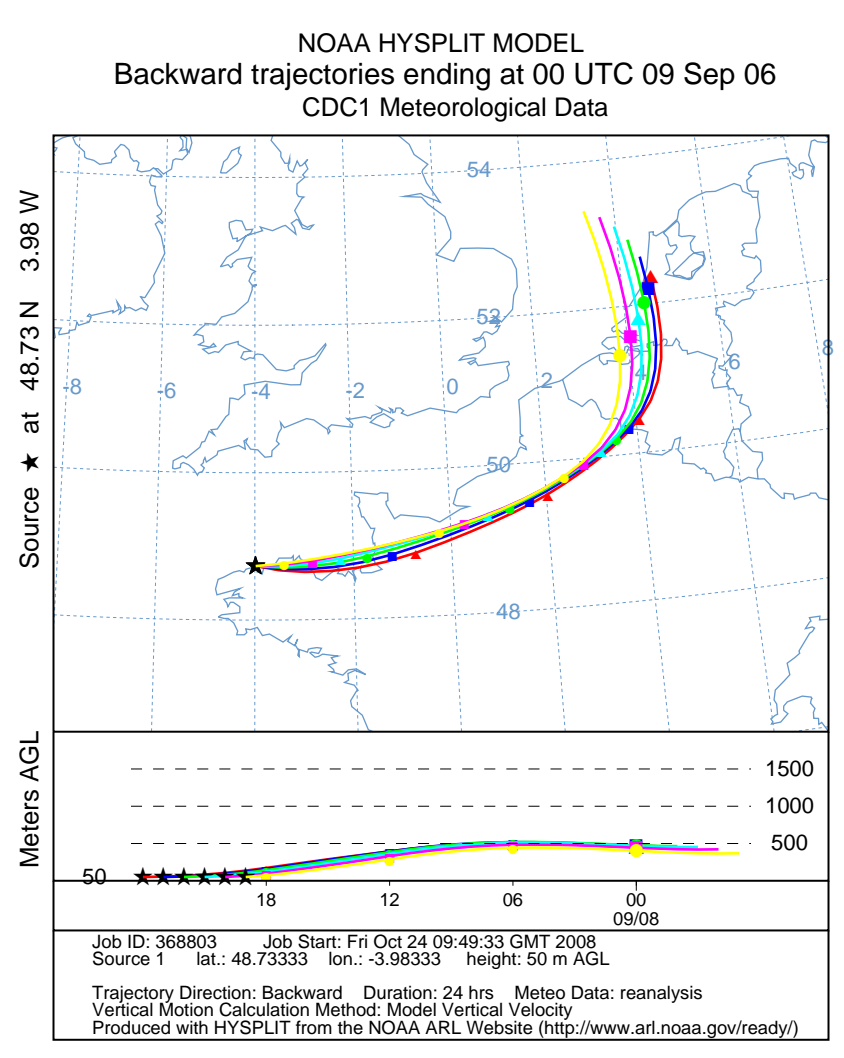

Fig. 8. Hourly back trajectories generated using the NOAA HYSPLIT model for the period 18:00 to midnight on 8 September 2006 (see Draxler and Rolph, 2003).

range $17-150 \mathrm{~nm} \mathrm{~h}^{-1}$. At Mace Head in Ireland, Dal Maso et al. (2002) estimated a range of $120-180 \mathrm{~nm} \mathrm{~h}^{-1}$ in clean marine air and $15-20 \mathrm{~nm} \mathrm{~h}^{-1}$ in polluted air advected over a tidal zone. The site at Roscoff is more complex than Mace Head with sources at various distances upwind (see Leigh et al., 2009, for a seaweed map and footprint analysis) as well as numerous pollution sources. As a result it is difficult to relate the range of apparent growth rates to sources without a larger dataset.

The apparent growth to greater than $120 \mathrm{~nm}$ diameter observed by single-point in situ measurement implies that the particle formation must be a widespread phenomenon over the Brittany coastline during the experimental period (see back-trajectories in Fig. 8). Since regionally, there may be significant additional sources of condensable material, it cannot be claimed that the particle growth results solely from the condensation of oxidation products of macroalgal emissions of iodine. Indeed, it is very likely that other condensable material significantly contribute to the particle growth as they dilute and mix into the semi-polluted atmosphere. However, from the relationships established in the current work and more widely within the RHaMBLe project it is clear that the regional scale enhancement in particle number, and under appropriate conditions $\mathrm{CCN}$ number, results from tidally driven iodine- and ozone-mediated particle formation. 


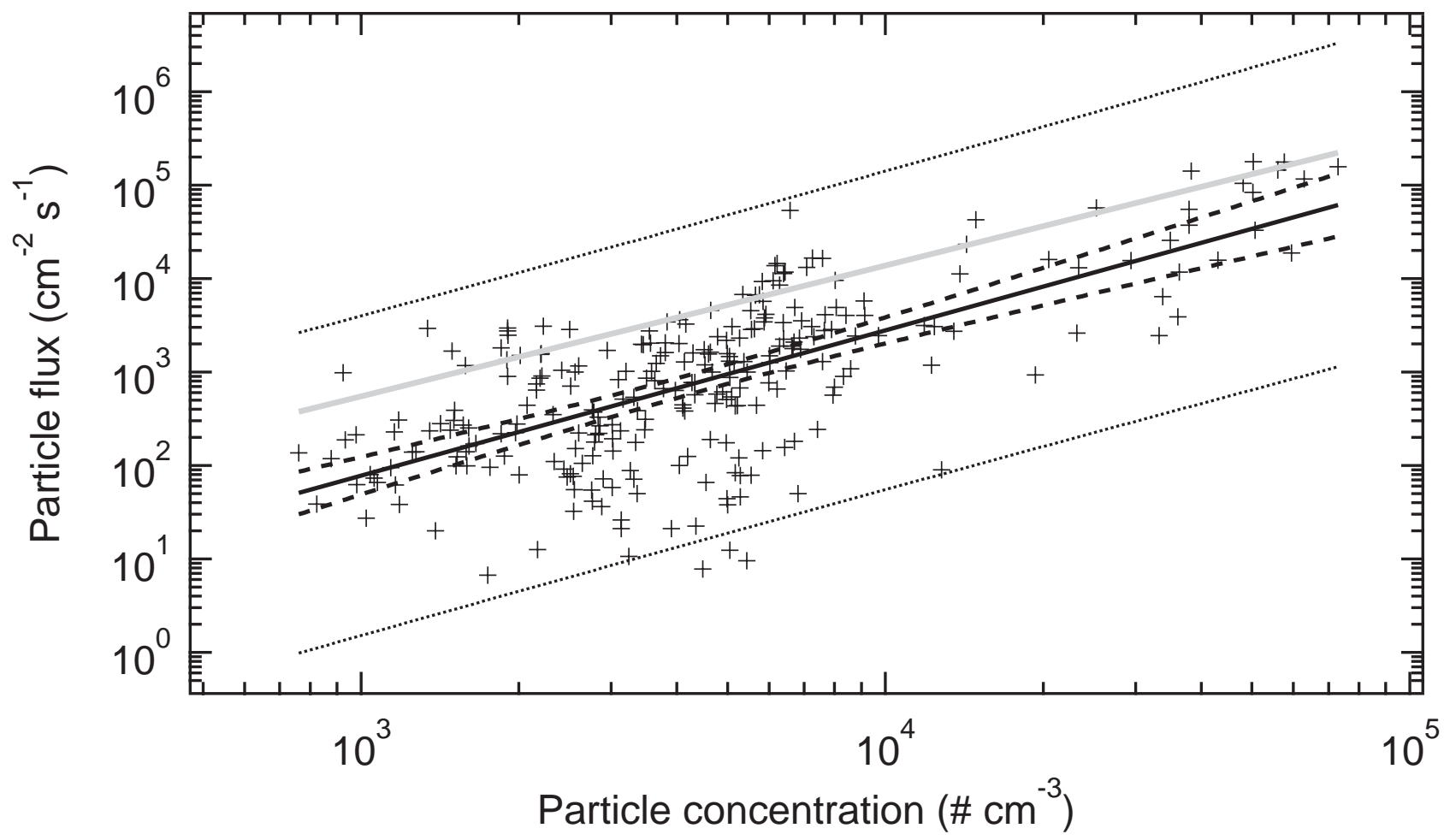

Fig. 9. Particle emission fluxes plotted as a function of number concentration. Also shown are the fit based on Eq. 5 (black line) and the $99 \%$ confidence (dashed) and prediction (dotted) intervals, as well as the relationship derived by Flanagan et al. (2005) (grey line).

\subsection{Particle fluxes}

Particle fluxes of the order of $10^{5}$ particles $\mathrm{cm}^{-2} \mathrm{~s}^{-1}$ were seen at Roscoff during the RHaMBLe experiment. In previous measurements of coastal particle emission fluxes, Flanagan et al. (2005) observed fluxes of up to $10^{6} \mathrm{~cm}^{-2} \mathrm{~s}^{-1}$ at Mace Head. Flanagan et al. (2005) was also able to derive a relationship between particle number fluxes and concentrations for clean marine air over a single source (no strong correlation could be found in air masses over multiple coastal sources). This was based on the formula:

$\log _{10} F=m \log _{10} N-k$

With $F$ the particle flux $\left(\mathrm{cm}^{-2} \mathrm{~s}^{-1}\right)$ and $N$ the number concentration $\left(\# \mathrm{~cm}^{-3}\right)$, Flanagan et al. (2005) derived the values $m=1.40 \pm 0.16$ and $k=1.46 \pm 0.65\left(r^{2}=0.86\right)$. A similar correlation was also found between the particle number fluxes and concentrations measured at Roscoff. Using Eq. (5), $m=1.56 \pm 0.26$ and $k=2.78 \pm 0.97$. Figure 9 shows this relationship and compares with that derived by Flanagan et al. (2005). The correlation is weaker $\left(r^{2}=0.47\right)$, but still significant $(p<0.001)$. This result is surprising as Flanagan et al. (2005) only observed a correlation when clean marine air passes over a single source region within $100 \mathrm{~m}$ of the measurement location. As discussed above, the site at Roscoff is more complex with multiple sources at various distances upwind of the measurement location and it must be stressed that Flanagan et al. (2005) only proposed the simplifying correlation for the single source events. This may explain the differences between the correlations seen at the two sites, but longer-term investigations would be needed to establish the dependence of the relationship between particle number fluxes and concentrations on source.

It should be noted here that it is likely that significant particle nucleation also occurs above the sensors, leading to an underestimate in the total apparent particle emission fluxes. The fluxes shown above and in Fig. 6 must therefore be lower limits at this location.

\section{Conclusions}

Measurements of ozone deposition velocities and ultrafine particle emission fluxes were made over an extensive infralittoral zone on the coast of Brittany, north-west France in September 2006. Strong particle bursts (with ultrafine particle concentrations up to $2.5 \times 10^{5}$ particles $\mathrm{cm}^{-3}$ ) were observed during the daytime low-tides. Enhanced uptake to the iodide-rich surfaces of exposed macroalgae resulted in higher $v_{d}\left[\mathrm{O}_{3}\right]$ during low tide both during daytime and night-time compared to high tide. Observed values of $v_{d}\left[\mathrm{O}_{3}\right]$ at low tide were at least twice as high during the day as at night, illustrating the importance of photochemical destruction as an additional removal mechanism for ozone in the coastal 
atmosphere. In good stationarity and fetch conditions, particle fluxes of up to $2 \times 10^{5}$ particles $\mathrm{cm}^{-2} \mathrm{~s}^{-1}$ were observed corresponding to the highest observed $v_{d}\left[\mathrm{O}_{3}\right]$ of $3 \mathrm{~mm} \mathrm{~s}^{-1}$, and a significant relationship was seen between particle number fluxes and concentrations. Apparent particle growth rates were estimated to be in the range $17-150 \mathrm{~nm} \mathrm{~h}^{-1}$ for particles greater than $3 \mathrm{~nm}$. These results link direct depositional loss and photochemical destruction of ozone to the formation of particles from macroalgal emissions at a coastal location. The apparent continuous growth of particles is indicative of large-scale formation of ultrafine particles and that they grow to sizes at which they will most likely act as $\mathrm{CCN}$ indicates a potential regional radiative impact.

Acknowledgements. The authors would like to acknowledge Philippe Potin and the staff of the Station Biologique de Roscoff for their kind assistance and the interest shown in our work by the people of Roscoff. Thanks also to James Lee of the University of York for providing the ozone concentration data. The authors gratefully acknowledge the NOAA Air Resources Laboratory (ARL) for the provision of the HYSPLIT transport and dispersion model and READY website (http://www.arl.noaa.gov/ready.html) used in this publication. The RHaMBLe project was funded under a NERC grant NE/D006570/1 within the UK SOLAS programme.

Edited by: R. von Glasow

\section{References}

Agarwal, J. K. and Sem, G. J.: Continuous flow, single-particlecounting condensation nucleus counter, J. Aerosol Sci., 11, 343357, 1980.

Ball, S. M., Hollingsworth, A. M., Humbles, J., Leblanc, C., Potin, P., and McFiggans, G.: Spectroscopic studies of molecular iodine emitted into the gas phase by seaweed, Atmos. Chem. Phys. Discuss., 9, 26329-26376, 2009,

http://www.atmos-chem-phys-discuss.net/9/26329/2009/.

Bariteau, L., Helmig, D., Fairall, C. W., Hare, J. E., Hueber, J., and Lang, E. K.: Determination of oceanic ozone deposition by shipborne eddy covariance flux measurements, Atmos. Meas. Tech. Discuss., 2, 1933-1972, 2009,

http://www.atmos-meas-tech-discuss.net/2/1933/2009/.

Buzorius, G., Rannik, Ü., Mäkelä, J. M., Vesala, T., and Kulmala, M.: Vertical aerosol particle fluxes measured by eddy covariance technique using condensational particle counter, J. Aerosol Sci., 29, 157-171, 1998.

Chamberlain, A. C.: Transport of gases to and from grass and grasslike surfaces, P. R. Soc. Lond. A, 290, 236-265, 1966.

Chang, W., Heikes, B. G., and Lee, M.: Ozone deposition to the sea surface: chemical enhancement and wind speed dependence, Atmos. Environ., 38, 1053-1059, 2004.

Clifford, D., Donaldson, D. J., Brigante, M., D’Anna, B., and George, C.: Reactive uptake of ozone by chlorophyll at aqueous surfaces, Environ. Sci. Technol., 42, 1138-1143, 2008.

Dal Maso, M., Kulmala, M., Lehtinen, K. E., Mäkelä, J. M., Aalto, P., and O'Dowd, C. D.: Condensation and coagulation sinks and formation of nucleation mode particles in coastal and boreal forest boundary layers, J. Geophys. Res., 107, 8097, doi:8010.1029/2001JD001053, 2002.

Dorsey, J. R., Nemitz, E., Gallagher, M. W., Fowler, D., Williams, P. I., Bower, K. N., and Beswick, K. M.: Direct measurements and parameterisation of aerosol flux, concentration and emission velocity above a city, Atmos. Environ., 36, 791-800, 2002.

Draxler, R. R. and Rolph, G. D.: HYSPLIT (HYbrid SingleParticle Lagrangian Integrated Trajectory) Model access via NOAA ARL READY Website, http://www.arl.noaa.gov/ready/ hysplit4.html, last access: October 2008, NOAA Air Resources Laboratory, Silver Spring, MD, 2003.

Fairall, C. W., Helmig, D., Ganzeveld, L., and Hare, J.: Waterside turbulence enhancement of ozone deposition to the ocean, Atmos. Chem. Phys., 7, 443-451, 2007, http://www.atmos-chem-phys.net/7/443/2007/.

Flanagan, R. J., Geever, M., and O'Dowd, C. D.: Direct measurements of new-particle fluxes in the coastal environment, Environ. Chem., 2, 256-259, 2005.

Foken, T. and Wichura, B.: Tools for quality assessment of surfacebased flux measurements, Agr. Forest Meteorol., 79, 83-105, 1996.

Foken, T.: Micrometeorology, Springer-Verlag, Berlin, 306 pp., 2006.

Gallagher, M. W., Beswick, K. M., and Coe, H.: Ozone deposition to coastal waters, Q. J. Roy. Meteorol. Soc., 127, 539-558, 2001.

Garland, J. A.: The dry deposition of sulphur dioxide to land and water surfaces, P. R. Soc. Lond. A, 354, 245-268, 1977.

Güsten, H., Heinrich, G., Schmidt, R. W. H., and Schurath, U.: A novel ozone sensor for direct eddy flux measurements, J. Atmos. Chem., 14, 73-84, 1992.

Güsten, H. and Heinrich, G.: On-line measurements ofo zone surface fluxes: Part I, Methodology and instrumentation, Atmos. Environ., 30, 897-909, 1996.

Kondo, J.: Air-sea bulk transfer coefficients in diabatic conditions, Bound.-Lay. Meteorol., 9, 91-112, 1975.

Küpper, F. C., Schweigert, N., Ar Gall, E., Legendre, J.-M., Vilter, H., and Kloareg, B.: Iodine uptake in Laminariales involves extracellular, haloperoxidase-mediated oxidation of iodide, Planta, 207, 163-171, 1998.

Küpper, F. C., Carpenter, L. J., McFiggans, G. B., Palmer, C. J., Waite, T. J., Boneberg, E.-M., Woitsch, S., Weiller, M., Abela, R., Grolimund, D., Potin, P., Butler, A., Luther III, G. W., Kroneck, P. M. H., Meyer-Klaucke, W., and Feiters, M. C.: Iodine accumulation provides kelp with an inorganic antioxidant impacting atmospheric chemistry, P. Natl. Acad. Sci., 105, 69546958, 2008.

Leigh, R. J., Ball, S. M., Whitehead, J., Leblanc, C., Shillings, A. J. L., Mahajan, A. S., Oetjen, H., Dorsey, J. R., Gallagher, M., Jones, R. L., Plane, J. M. C., Potin, P., and McFiggans, G.: Measurements and modelling of molecular iodine emissions, transport and photodestruction in the coastal region around Roscoff, Atmos. Chem. Phys. Discuss., 9, 21165-21198, 2009, http://www.atmos-chem-phys-discuss.net/9/21165/2009/.

Liss, P. S. and Merlivat, L.: Air-sea gas exchange rates: Introduction and synthesis, in: The Role of Air-Sea Exchange in Geochemical Cycling, edited by: Buat-Ménard, P. and Reidel, D., Dordrecht, 113-129, 1986.

Mårtensson, E. M., Nilsson, E. D., Buzorius, G., and Johansson, C.: Eddy covariance measurements and parameterisation of 
traffic related particle emissions in an urban environment, Atmos. Chem. Phys., 6, 769-785, 2006,

http://www.atmos-chem-phys.net/6/769/2006/.

Martino, M., Mills, G. P., Woeltjen, J., and Liss, P. S.: A new source of volatile organoiodine compounds in surface seawater, Geophys. Res. Lett., 36, L01609, doi:10.1029/2008GL036334, 2009.

McFiggans, G. B., Plane, J. M. C., Allan, B. J., Carpenter, L. J., Coe, H., and O'Dowd, C.: A modelling study of iodine chemistry in the marine boundary layer, J. Geophys. Res., 105, 1437114385, 2000.

McFiggans, G., Coe, H., Burgess, R., Allan, J., Cubison, M., Alfarra, M. R., Saunders, R., Saiz-Lopez, A., Plane, J. M. C., Wevill, D., Carpenter, L., Rickard, A. R., and Monks, P. S.: Direct evidence for coastal iodine particles from Laminaria macroalgae - linkage to emissions of molecular iodine, Atmos. Chem. Phys., 4, 701-713, 2004,

http://www.atmos-chem-phys.net/4/701/2004/.

McFiggans, G. B.: Marine aerosols and iodine emissions, Nature, 433, E13, doi:10.1038/nature03372, 2005.

McFiggans, G., Bale, C. S. E., Ball, S. M., Beames, J. M., Bloss, W. J., Carpenter, L. J., Dorsey, J., Dunk, R., Flynn, M. J., Furneaux, K. L., Gallagher, M. W., Heard, D. E., Hollingsworth, A. M., Hornsby, K., Ingham, T., Jones, C. E., Jones, R. L., Kramer, L. J., Langridge, J. M., Leblanc, C., LeCrane, J.-P., Lee, J. D., Leigh, R. J., Longley, I., Mahajan, A. S., Monks, P. S., Oetjen, H., Orr-Ewing, A. J., Plane, J. M. C., Potin, P., Shillings, A. J. L., Thomas, F., von Glasow, R., Wada, R., Whalley, L. K., and Whitehead, J. D.: Iodine-mediated coastal particle formation: an overview of the Reactive Halogens in the Marine Boundary Layer (RHaMBLe) Roscoff coastal study, Atmos. Chem. Phys. Discuss., 9, 26421-26489, 2009,

http://www.atmos-chem-phys-discuss.net/9/26421/2009/.

Muller, J. B. A., Percival, C. J., Gallagher, M. W., Fowler, D., Coyle, M., and Nemitz, E. G.: Sources of uncertainty in eddy covariance ozone flux measurements made by dry chemiluminescence fast response analysers, Atmos. Meas. Tech. Discuss., 2, 2241-2280, 2009 ,

http://www.atmos-meas-tech-discuss.net/2/2241/2009/.

Nemitz, E., Gallagher, M. W., Duyzer, J. H., and Fowler, D.: Micrometeorological measurements of particle deposition velocities to moorland vegetation, Q. J. Roy. Meteorol. Soc., 128, 2281-2300, 2002.

O’Dowd, C. D., Geever, M., Hill, M. K., Smith, M. H., and Jennings, S. G.: New particle formation: Nucleation rates and spatial scales in the clean marine coastal environment, Geophys. Res. Lett., 25, 1661-1664, 1998.

O’Dowd, C., Jimenez, J. L., Bahreini, R., Flagan, R. C., Seinfeld, J. H., Hämeri, K., Pirjola, L., Kulmala, M., Jennings, S. G., and Hoffmann, T.: Marine aerosol formation from biogenic iodine emissions, Nature, 417, 632-636, 2002a.
O’Dowd, C. D., Hämeri, K., Mäkelä, J. M., Väkeva, M., de Leeuw, G., Kunz, G. J., Becker, E., Hansson, H.-C., Allen, A. G., Harrison, R. M., Berresheim, H., Kleefeld, C., Geever, M., Jennings, S. G., and Kulmala, M.: Coastal new particle formation: Environmental conditions and aerosol physicochemical characteristics during nucleation bursts, J. Geophys. Res., 107, 8107, doi:8110.1029/2000JD000206, 2002b.

O'Dowd, C. D. and Hoffmann, T.: Coastal new particle formation: A review of the current state-of-the-art, Environ. Chem., 2, 245255, 2005.

Owen, P. R. and Thomson, W. R.: Heat transfer across rough surfaces, J. of Fluid Mech., 15, 321-334, 1963.

Palmer, C. J., Anders, T. L., Carpenter, L. J., Küpper, F. C., and McFiggans, G. B.: Iodine and halocarbon response of Laminaria digitata to oxidative stress and links to atmospheric new particle production, Environ. Chem., 2, 282-290, 2005.

Paulson, C. A.: The mathematical representation of wind speed and temperature profiles in the unstable atmospheric surface layer, J. Appl. Meteorol., 9, 857-861, 1970.

Pirjola, L., O'Dowd, C. D., and Kulmala, M.: A model prediction of the yield of cloud condensation nuclei from coastal nucleation events, J. Geophys. Res., 107, 8098, doi:10.1029/2000JD000213, 2002.

Pryor, S. C., Gallagher, M. W., Sievering, H., Larsen, S. E., Barthelmie, R. J., Birsan, F., Nemitz, E., Rinne, J., Kulmala, M., Grönholm, T., Taipale, R., and Vesala, T.: A review of measurement and modelling results of particle atmosphere-surface exchange, Tellus, 60B, 42-75, 2008.

Saiz-Lopez, A., Plane, J. M. C., McFiggans, G., Williams, P. I., Ball, S. M., Bitter, M., Jones, R. L., Hongwei, C., and Hoffmann, T.: Modelling molecular iodine emissions in a coastal marine environment: the link to new particle formation, Atmos. Chem. Phys., 6, 883-895, 2006, http://www.atmos-chem-phys.net/6/883/2006/.

Saiz-Lopez, A., Saunders, R. W., Joseph, D. M., Ashworth, S. H., and Plane, J. M. C.: Absolute absorption cross-section and photolysis rate of $\mathrm{I}_{2}$, Atmos. Chem. Phys., 4, 1443-1450, 2004, http://www.atmos-chem-phys.net/4/1443/2004/.

Schwartz, S. E.: Factors governing dry deposition of gases to surface water, in: Precipitation Scavenging and AtmosphereSurface Exchange, edited by: Schwartz, S. E. and Slinn, W. G. N., 789-801, 1992.

Webb, E. K., Pearman, G. I., and Leuning, R.: Correction of flux measurements for density effects due to heat and water vapour transfer, Q. J. Roy. Meteorol. Soc., 106, 85-100, 1980.

Whitehead, J. D., McFiggans, G. B., Gallagher, M. W., and Flynn, M. J.: Direct linkage between tidally driven coastal ozone deposition fluxes, particle emission fluxes, and subsequent CCN formation, Geophys. Res. Lett., 36, L04806, doi:10.1029/2008GL035969, 2009. 